\title{
Reading Frame
}

National Cancer Institute

\section{Source}

National Cancer Institute. Reading Frame. NCI Thesaurus. Code C63552.

One of the three possible ways of reading a nucleotide sequence. As the genetic code is read in nonoverlapping triplets (codons) there are three possible ways of translating a sequence of nucleotides into a protein, each with a different starting point. 